\title{
混合粒径砂を用いた大型海浜実験による粒径別 浮遊砂フラックスとモデル化
}

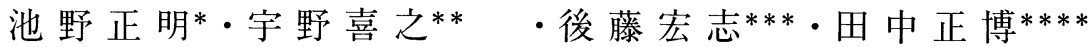 \\ 森信人*・片山裕之*****. 岡安章夫******
}

\section{1.はじめに}

砕波帯内では海底砂が顕著に巻き上げられ浮遊砂現象 が卓越する. 海浜変形モデルの精度向上のためには浮遊 漂砂の特性を把握し漂砂量の算定に適切に反映させる必 要がある。これまで単一粒径砂を対象に実験により砕波 帯内外における浮遊漂砂特性が解明されモデル化がなさ れている(柴山ら，1994；池野ら，1998).しかしながら， 細砂と粗砂が混在した混合粒径砂海浜の場合の浮遊漂砂 特性はまだ十分解明されておらずモデル化も十分になさ れていない.

そこで, 本研究では細砂と粗砂が混在した混合粒径砂 を対象に大型造波水路を用いて岸沖海浜变形実験を実施 し, 浮遊砂の粒径別特性を外力と採水を併用した浮遊砂 濃度計測により検討する。ついで, これらの特性を考慮 して浮遊砂の粒径別巻き上げ量と粒径別濃度鉛直分布を 再現できるモデルを提案する。

\section{2. 大型岸沖海浜実験による浮遊砂計測}

\section{（1）実験条件および実験方法}

長さ $205 \mathrm{~m}$, 幅 $3.4 \mathrm{~m}$, 高さ $6 \mathrm{~m}$ の大型造波水路に, 粒 径 $0.2 \mathrm{~mm}$ の細砂と粒径 $0.8 \mathrm{~mm}$ の粗砂を $70 \%$ 対 $30 \%$ の割合で一様に混合した砂を初期勾配 $1 / 30$ で敷き詰め た.まず, 堆積性波浪として波高 $0.3 \mathrm{~m}$ 周期 $3.5 \mathrm{~s}$ の規則 波を $38 \mathrm{hr}$ 作用させた後, 地形を整形せずに侵食性波浪 として波高 $1 \mathrm{~m}$ 周期 $3.5 \mathrm{~s}$ の規則波を $20 \mathrm{hr}$ 作用させた (田中ら，2000).

この間有意に地形変化が生じた度に繰り返し外力およ

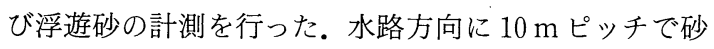
面上 $10 \mathrm{~cm}$ と $50 \mathrm{~cm}$ の高さに取り付けた濃度計と鉛直 面 2 次元電磁流速計㧍よび容量式波高計により砕波帯内 外の下層・中層での浮遊砂フラックスを計測するととも に, 移動式台車に取り付けた濃度計と 3 次元超音波ドッ

\footnotetext{
$*$ 正会員 工博 (財)電力中央研究所 主任研究員 我孫子研究所

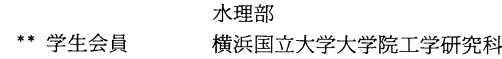

*** 相模鉄道株式会社

**** 正 会 員 工修 東京電力株式会社

***** 正 会 員 工修 横浜国立大学助手 大学院工学研究科

******* 正 会 員 工博 横浜国立大学大学院助教授 工学研究科
}

プラー流速計および容量式波高計により砕波帯内の 3 次 元浮遊砂フラックスの鉛直分布を鉛直方向に $20 \mathrm{~cm}$ ピッチで計測した。計測時のサンプリング周波数は 20 $\mathrm{Hz}$, サンプリング時間は 3 分間あるいは 6 分間である.

\section{（2）採水と濃度計による浮遊砂濃度の計測方法}

浮遊砂濃度の計測には光学式後方散乱型および透過型 の濃度計を使用した。本実験では，濃度計による計測と ともに，以下に述べる 2 種類の採水方法を併用し，これ により得られた浮遊砂を粒度分析により細砂と粗砂に分 離し浮遊砂の混合率と粒径別浮遊砂濃度を求めた。

採水用ホース口を各濃度計と同じ位置に波進行方向と 垂直になるように水平に水路内に取り付ける。まず，毎 秒高速採水(HSWSS) として, 水路内の水を造波水路の 外にガソリンエンジンポンプに取り付けたホースで汲み 上げ, $500 \mathrm{ml}$ の採水容器に毎秒 1 サンプルを採取する. これを 40 秒間行い計 40 サンプルを採取し 40 秒間の濃 度時系列を算出する (片山ら，1999）。

つぎに， 2 分間連続採水として，ホースで汲み上げ 97 $\mu \mathrm{m}$ メッシュのプランクトンネットからなる捕砂器で 2 分間ろ過して砂のみを採取する. 捕砂器を通過した水を 排水する際に流量計により採水流量を計測し，これより 時間平均濃度を算出する，本実験で使用する粗砂および 細砂の沈降速度は各々 $0.077 \mathrm{~m} / \mathrm{s}, 0.025 \mathrm{~m} / \mathrm{s}$ であるのに 対し, ホース内の流速は $1.7 \mathrm{~m} / \mathrm{s}$ 程度であり十分な管内 流速である。

上記の方法で得られた捕砂濃度を参照し, 濃度計によ る電圧值から濃度值へのキャリブレーション值のクロス チェックを行った(片山ら，1999)。特に混合粒径砂の場 合には, 濃度計の出力電圧值が厳密には細砂と粗砂の混 合率によって変化し, 粗砂の混入率が顕著に増加すると, 同じ濃度でも出力電圧值が低下することがわかった。こ のため, 別途攪乱装置を用いて粗砂の混入率の異なる混 合砂を対象に濃度計の検定を実施し粗砂の混入率に応じ たキャリブレーション值の補正も行った。

\section{3. 粒径別浮遊砂濃度・フラックスの特性}

（1）濃度計のキャリブレーション

濃度計の出力電圧值を濃度値へ変換するためにキャリ 


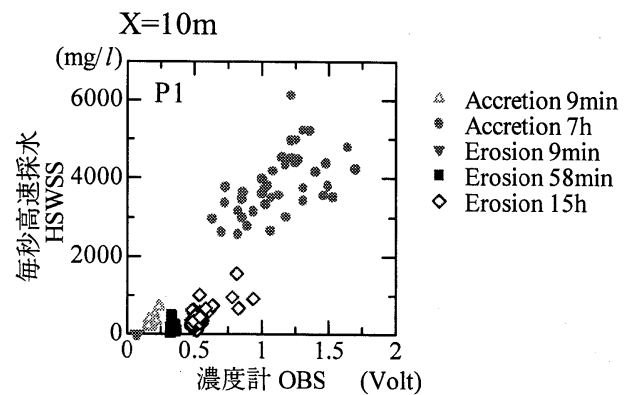

図一1＼cjkstart毎秒高速採水と濃度計による時系列の相関例

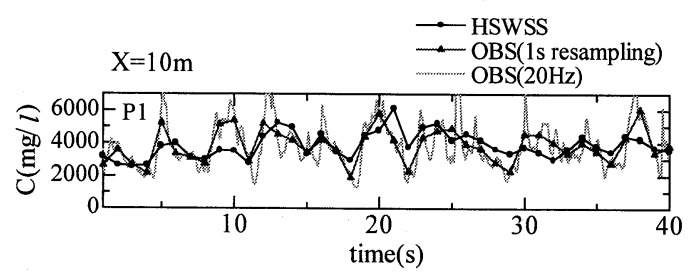

図一2 キャリブレーション後の毎秒高速採水と濃度計によ る時系列の比較（堆積性 $7 \mathrm{hr}$ ）

ブレーション值(傾きとバックグランド值)を適切に決定 する必要がある.本研究では, まず, サンプリング周波数 $20 \mathrm{~Hz}$ で計測された濃度計デー夕を毎秒高速採水と同じ デー夕数に揃えるために $1 \mathrm{~s}$ 区間移動平均を施した。図 -1に,無秒高速操水に上る捕砂濃度時系列と, $1 \mathrm{~s}$ 区間 移動平均後の出力電圧時系列との相関図の代表例を示 す.この際に得られる 1 次回帰直線の傾きを採用した(概 して 3,900 ppm/Volt).つぎに, この傾きを用いて濃度計 時系列の時間平均値と 2 分間連続採水による時間平均捕 砂濃度が一致するようにバックグランド值を決定した。 なお, 本実験では浮遊砂中の粗砂の混入率は, 顕著に巻き 上がる砕波点付近でも最大で $20 \%$ 程度であった。

图一2 は，上記の方法により決めたキャリブレーショ ン值を用いた濃度計時系列と捕砂濃度時系列の比較例で ある.図中には濃度計による計測サンプリング $20 \mathrm{~Hz}$ 毎 の時系列と,1s区間移動平均を施した後の時系列を併記し ている.図一2によると,1s区間移動平均後の濃度計デー 夕と毎秒高速採水による時系列のピーク值等はほぼ一致 し適切なキャリブレーションがなされていることがわかる.

\section{（2）堆積性波浪による粒径別浮遊砂特性}

図一3に，堆積性波浪の浮遊砂計測時の波高分布と海 底地形変化を示す.このケースでは，まず， $X=15 \mathrm{~m}$ の 地点に小さなバーが形成され (波作用後 $1 \mathrm{hr}$ ), 次第に岸 側へ移動するが $(6.6 \mathrm{hr})$, やがて消滅し侵食域に転じる とともに $(15 \mathrm{hr})$, 張ら $(1994 ； 1995 ； 1996)$ と同様に, $\mathrm{X}=10 \mathrm{~m}$ から岸側に主に粗砂が堆積し (30 hr), 最終地形

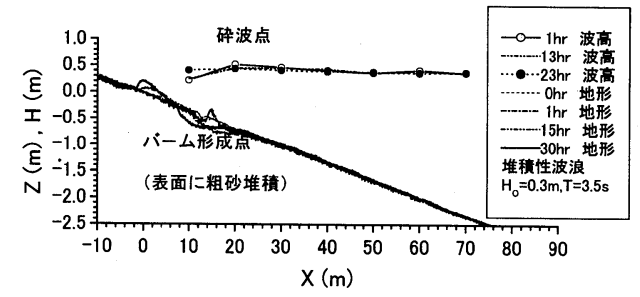

図一３堆積性波浪作用時の波高分布と地形変化

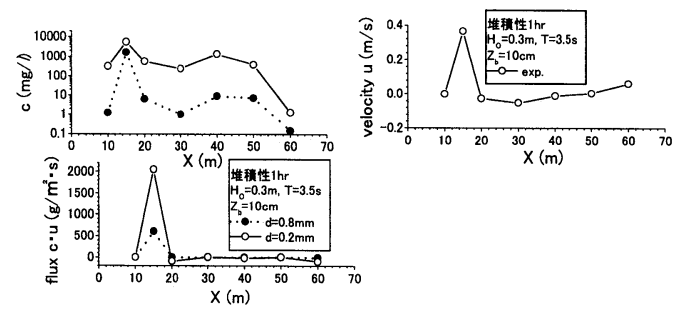

（a）底面上 $10 \mathrm{~cm}$ の高さに扔ける岸沖分布（堆積性 $1 \mathrm{hr}$ )

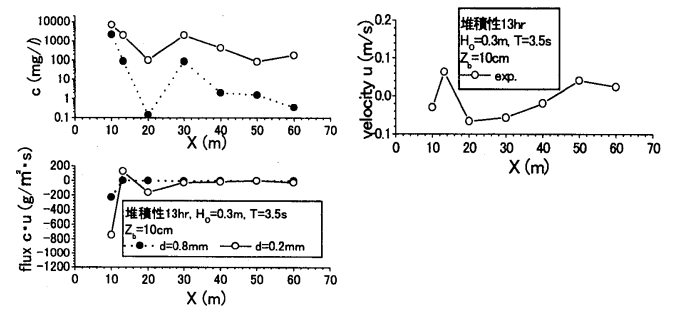

（b）底面上 $10 \mathrm{~cm}$ の高さにおける岸沖分布（堆積性 $13 \mathrm{hr}$ ）

図一4 堆積性波浪による粒径別浮遊砂濃度・定常流速・フ ラックスの特性

を形成した $(38 \mathrm{hr}) .6 .6 \mathrm{hr}$ と $38 \mathrm{hr}$ の地形の揭載は省略 している.この間, 砕波点は $X=15 \mathrm{~m}$ の地点加ら $X=12$ $\mathrm{m}$ の地点まで次第に岸側へ移動している。このケースで は plunging 砕波であった。

図一 4 に，堆積性波浪作用時の粒径別時間平均浮遊砂 濃度 $c$, 岸沖定常流速 $u$, 岸沖粒径別時間平均フラックス $\mathrm{c} \cdot \mathrm{u}$ の代表例を示す. 図（a）が $1 \mathrm{hr}$ 後, 図（b）が $13 \mathrm{hr}$ 後における底面上 $10 \mathrm{~cm}$ の高さにおける岸沖分布であ る．流速およびフラックスは沖向きが正の值である．ま ず，図（a）によれば，このケースの初期の段階では，砕 波点 $X=15 \mathrm{~m}$ の地点で最も激しく巻き上げられ, 粗砂 $1,700 \mathrm{ppm}$ ，細砂 5,600 ppm の濃度が得られている.

この場合のフラックスは, 粗砂·細砂とも $X=40 \mathrm{~m}$ よ り沖側ではやや沖向きに小さな值, $X=40 \sim 20 \mathrm{~m}$ では岸 向き, $X=15 \mathrm{~m}$ の砕波点では沖向きに大きな值となって いる.つぎに，図 (b) によれば，砕波点が岸側へ移動し たのに伴い, 砕波点付近の $X=10 \mathrm{~m}$ の地点で粗砂 2,200 $\mathrm{ppm}$, 細砂 7,100 ppm の濃度が得られている。この場合 のフラックスは, $X=20 \mathrm{~m}$ より沖側では上記と同様の傾 


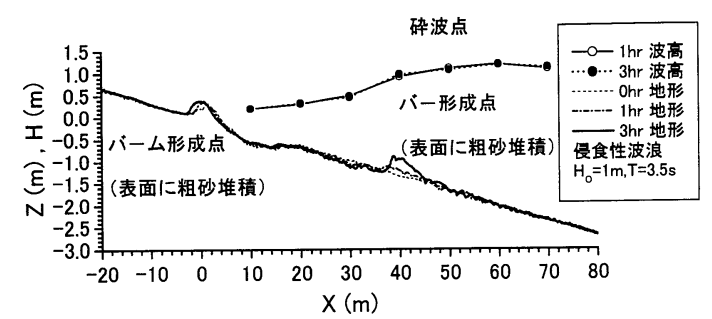

图一5 侵食性波浪作用時の波高分布と地形変化
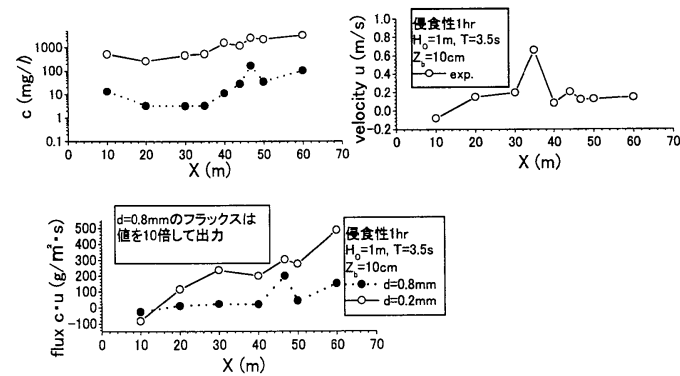

(a) 底面上 $10 \mathrm{~cm}$ の高さにおける岸沖分布
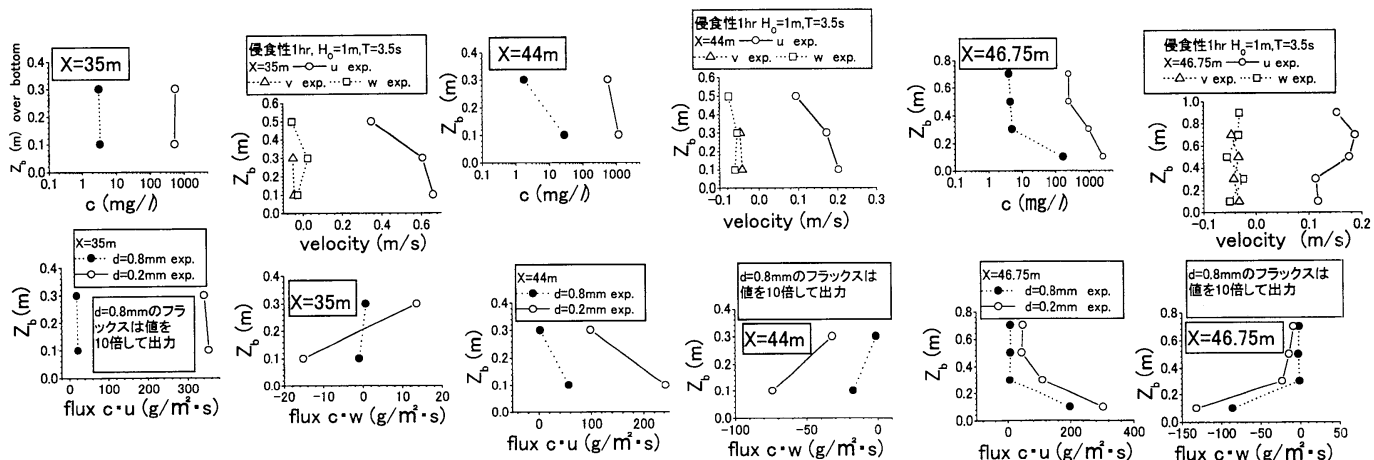

(b) 鉛直分. 布
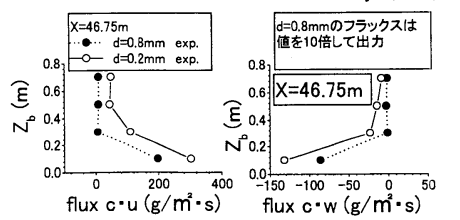

図一6 侵食性波浪による粒径別浮遊砂濃度・定常流速・フラックスの特性（侵食性 $1 \mathrm{hr}$ ）

向であるが，粗砂・細砂とも $X=10 \mathrm{~m}$ の地点で岸向きに 大きな值に変化している.

\section{（3）侵食性波浪による粒径別浮遊砂特性}

つぎに, 図一 5 に, 侵食性波浪の浮遊砂計測時の波高分 布と海底地形変化を示す.このケースでは， $X=40 \mathrm{~m}$ 付 近にバーが形成され始め(波作用後 $1 \mathrm{hr}$ ), バーは発達し ながら次第に沖側へ移動し $(3 \mathrm{hr})$, 図面の掲載は省略す るが, $20 \mathrm{hr}$ 後には $X=50 \mathrm{~m}$ の地点まで沖側へ $10 \mathrm{~m}$ 程 度移動した。このバーの表層には，張ら（1994；1995； 1996）と同様に粗砂が堆積した。この間，前ケースで汀 線付近に形成されたバームは徐々に岸側に移動している が, 表層に堆積した粗砂が流出することはなかった。こ のケースでは plunging 砕波であった。

図一6に, 侵食性波浪 $1 \mathrm{hr}$ 作用時の粒径別時間平均浮 遊砂濃度, 定常流速, 粒径別時間平均フラックスの代表 例を示す. 図 (a) が砂面上 $10 \mathrm{~cm}$ の高さにおける岸沖分 布，図 (b) が碑波帯内の代表地点における鉛直分布であ る. 図中, $u, v, w$ は岸沖方向・水路奥行き方向・鉛直 方向流速であり, $u$ は沖向き正, $v$ は図-5に対して紙面 表向き正， $w$ は鉛直上向き正であり，フラックスの向き も流速の向きの定義に準ずる. 図一6によると, 侵食性波 浪の場合は，砕波帯内外に渡って全体的に粗砂・細砂の 濃度が高く, $X=40 \sim 50 \mathrm{~m}$ の区間の砕波点付近では, 粗 砂の濃度が最大值を示す. 砕波点付近における濃度の最
大值自体は，堆積性波浪時の砕波点付近における濃度の 最大値に比べて小さくなっている。これは，堆積性波浪 時には $X=10 \sim 15 \mathrm{~m}$ の浅海域で砕波が生じるため, 砕 波による大規模渦が減衰拡散することなく直接海底面に 到達し, より顕著に砂を巻き上げるものと推察される. この場合のフラックスは, $X=20 \mathrm{~m}$ から沖側では沖向き の大きい值, $X=10 \mathrm{~m}$ の地点では岸向きであった.

砕波帯内のフラックスの鉛直分布を見ると, バー形成 点のやや沖にあたる $X=46.75 \mathrm{~m}$ での粗砂と細砂のフ ラックスを水深方向に積分すると, 各々 $0.003 \mathrm{~cm}^{3} / \mathrm{cm} / \mathrm{s}$ と $0.6 \mathrm{~cm}^{3} / \mathrm{cm} / \mathrm{s}$ 程度の浮遊漂砂量となる. また, この地 点では沖向きフラックスの半分程度の值の鉛直下向きフ ラックスも存在している。これは, 海底斜面に沿って斜 め下沖向きに浮遊砂が移動していることを意味してい る.バーの岸側にあたる $\mathrm{X}=35 \mathrm{~m}$ では, 粗砂・細砂の濃 度やフラックスが海底面から上に行っても, あまり低減 せず，水深方向にほぼ一様に沖向きのフラックスとなっ ているが，鉛直方向のフラックス成分は小さい.

\section{4. 浮遊砂の粒径別巻き上げ量と濃度鉛直分布 のモデル化}

\section{（1） 粒径別巻き上げ量のモデル化}

以上の実験結果に基づき，まず混合海底砂の粒径別巻 き上げ量（基準点濃度）のモデル化を試みる，上記の堆 


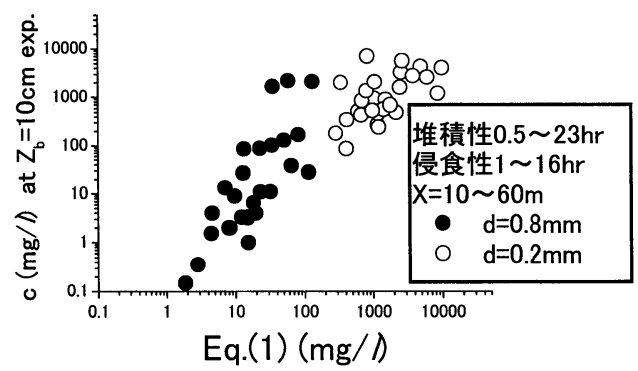

図一7 粒径別巻き上げ量の算定式による実験結果の再現例

積性㧍よび侵食性波浪による実験結果とも，細砂・粗砂 とも巻上げ量は各々の粒径と底面流速に応じたシールズ 数の 1.5 乗に比例していた。 また, 細砂·粗砂とも各々の シールズ数が 0.05 よりも大きくなると巻き上げが生じ ることもわかった．さらに，粗砂および細砂の巻上げ量 と各々の粒径砂が $100 \%$ の場合の既往の巻上げ量（柴山 ら，1994）との比は，海底砂面表層の粗砂と細砂の混合 率に対応していることも明らかとなった.

そこで，まず上記の特性を考慮してモデル化を試みる。 $\mathrm{N}$ 種類の粒径砂から構成される混合海底砂における $\mathrm{i}$ 番 目の粒径 $d_{i}$ に対する粒径別巻き上げ量 $p_{i}$ (基準点濃度 $\left.c_{0 i}\right)$ の算定式として次式を提案する.

$$
c_{0 i}=\frac{p_{i}}{w_{s i}}=P_{i} A^{\prime} \rho_{w} \frac{\left(\Psi_{i}-0.05\right)^{1.5} \nu}{\sqrt{\left(\rho_{s} / \rho_{w}-1\right) d_{i}} 100 d_{i}}
$$

ここに, $w_{s i}$ は粒径 $d_{i}$ に対する沈降速度, $\rho_{w}$ と $\rho_{s}$ は水と 砂の密度, $P_{i}$ は海底砂面表層の粒径 $d_{i}$ の砂の混入率, $\Psi_{i}$ は粒径 $d_{i}$ の砂のシールズ数, $\nu$ は水の動粘性係数であ る. $A^{\prime}$ は係数で 3.0 の值とした. また，ここでは便宜上 基準点濃度を与える位置は海底砂面上各々の粒径の 100 倍の高さとした。

図一7 は，堆積性および侵食性波浪による砕波帯内外 における底面付近の粗砂と細砂の時間平均濃度の実験值 と本提案式 (1)による算定值との比較例である. 式 (1) 中のシールズ数 $\Psi_{i}$ の算定に用いる底面流速振幅には実 測值を入力した。な扔，海底砂面表層の粗砂と細砂の混 合率は, 海底砂面計測とコアサンプリングを併用して算 定した海底砂の粗砂と細砂の混合率分布図（田中ら,

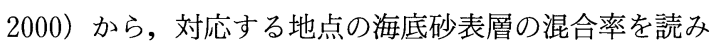
取って算定式に入力した。图一7 によると, 実験結果と式 （1）との相関は高く，粗砂と細砂の巻き上げ量（基準点 濃度）を適切に推定できるものと判断できる.

\section{（2）粒径別濃度鉛直分布のモデル化}

つぎに，以下に示す 3 タイプの濃度鉛直分布モデルを 構築して粗砂と細砂に対して代表地点に対し適用性を比 較検討する.

1）MODEL 1：砕波による渦粘性の鉛直分布を考慮
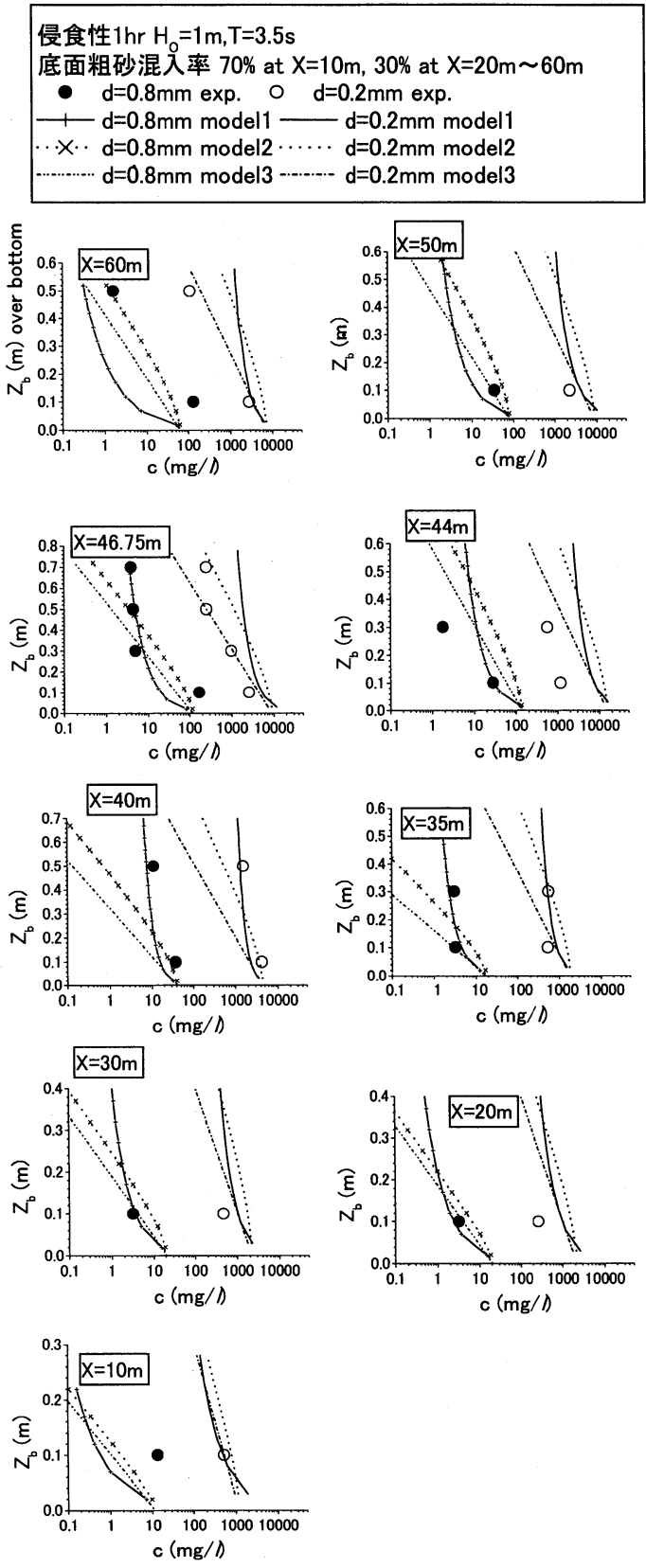

図一8 粒径別浮遊砂濃度の鉛直分布のモデルによる再現例 （侵食性 $1 \mathrm{hr}$ ）

したモデル

柴山ら（1994）にならい，鉛直拡散係数が海底面から の鉛直高さに比例し渦粘性係数の関数になると仮定する ことにより，時間平均鉛直 1 次元拡散方程式とその解を 混合粒径砂の場合に拡張して以下のように算定する.

$$
c_{i}\left(z_{b}\right) w_{s i}+\varepsilon_{s s i} z_{b} \frac{\partial c_{i}\left(z_{b}\right)}{\partial z_{b}}=0
$$




$$
c_{i}\left(z_{b}\right)=c_{0 i}\left(100 d_{i} / z_{b}\right)^{w_{s i} / M_{i}^{\prime}}
$$

ここに, $z_{b}$ は海底砂面上の鉛直高さ, $\varepsilon_{s s i}\left(=M_{i}^{\prime}\right)$ は粒径別 渦粘性係数で一様粒径砂に対する柴山ら (1994)の提案式 を粗砂と細砂に適用できるように次式のように修正する。

$$
\varepsilon_{s s i}=M_{i}^{\prime}=k_{1} u_{* i}+k_{2} k_{3} k_{4 i}\left(H^{3} g / 4 T h\right)^{1 / 3}
$$

ここに, $u_{* i}$ は粒径 $d_{i}$ の砂に対する底面摩擦速度, $g$ は重 力加速度, $H$ は波高, $T$ は周期, $h$ は水深, $k_{1}(=0.04)$ および $k_{2}(=0.216)$ は plunging 型砕波の場合の係数であ り, $k_{3}(=0.3 \sim 1.0)$ は砕波点から砕波帯内に渡り変化す る係数である(柴山ら，1994)． $k_{4 i}$ は混合粒径砂のために 新たに導入した係数であり，砕波による乱れが粒径別拡 散に及ぼす影響を考慮して粗砂 1.0 , 細砂 0.4 とした。

2) MODEL 2：移流・拡散混合モデル

Nielsen (1992) および Ikeno•Shimizu（1998）になら い, 時間平均鉛直 1 次元拡散方程式に鉛直移流効果を付 加した式（5）およびその解式（6）を混合粒径砂に対 して拡張する。

$$
\begin{aligned}
& w_{s i} \frac{\partial c_{i}\left(z_{b}\right)}{\partial z_{b}}+\varepsilon_{s i} \frac{\partial^{2} c_{i}\left(z_{b}\right)}{\partial z_{b}{ }^{2}}+\frac{p_{i}}{L_{s i}} \exp \left(-z_{b} / L_{s i}\right)=0 \\
& c_{i}\left(z_{b}\right)=c_{0 i}\left\{\frac{1}{1-\frac{\varepsilon_{s i}}{w_{s i} L_{s i}}} \exp \left(-z_{b} / L_{g i}\right)\right. \\
& \left.+\left(-1 \frac{1}{1-\frac{\varepsilon_{s i}}{w_{s i} L_{s i}}}\right) \exp \left(-w_{s i} z_{b} / \varepsilon_{s i}\right)\right\}
\end{aligned}
$$

ここに, $\varepsilon_{s i}$ と $L_{s i}$ は粒径 $d_{i}$ の砂の鉛直拡散係数と鉛直移 流スケール長であり，次式を援用する（Nielsen, 1988).

$$
\begin{aligned}
& \varepsilon_{s i}=w_{s i} \zeta\left[1.24 \exp \left\{-40\left(w_{s i} / \widehat{u}_{b}\right)^{2}\right\}+0.2\right] \cdots(7)
\end{aligned}
$$

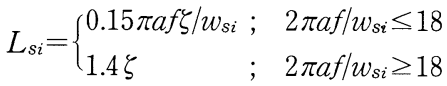

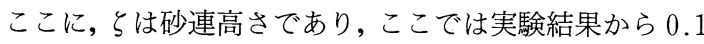
$\mathrm{m}$ とする. $\widehat{u}_{b}$ は底面岸沖流速の振幅, $a$ は水位振幅, $f$ は 入射波の周波数である.

3) MODEL 3 : 拡散のみのモデル

上記式（5）および式（6）中の移流寄与項を省略す ることにより ( $L_{s i} \rightarrow 0, \varepsilon_{s i} / L_{s i} \rightarrow$ 無限大), 通常の拡散の みのモデルとして算定する。

\section{(3) 実験結果の再現}

図一8 は，侵食性波浪による砕波帯内外代表地点にお ける粒径別濃度鉛直分布の 3 タイプのモデルによる再現 例である.図一 8 にると, 砕波点より沖では拡散のみの モデル，砕波点あるいはバーのやや沖では移流・拡散混 合モデル，砕波帯内あるいはバーの頂点から岸にかけて は渦粘性の鉛直分布を考慮したモデルが有効であること がわかる。

\section{5. 結 論}

1）混合砂大型実験により, 砕波帯内外の粒径別浮遊 砂濃度・フラックスの特性を明らかにした。

2）粒径別巻き上げ量の算定式を提案し 3 タイプの 濃度鉛直分布モデルを構築して適用性を検討した結果， 砕波点より沖では拡散のみのモデル，砕波点あるいは バーのやや沖では移流・拡散混合モデル, 砕波帯内ある いはバーの頂点から岸にかけては渦粘性の鉛直分布を考 慮したモデルが有効である。

本実験は東京電力 (株) と (財) 電力中央研究所の共同研 究 (LAMBDA-I) として, 東京大学と横浜国立大学の協 力のもとに実施したものである. 本実験を遂行するにあ たり, 東京大学港湾研究室の先生方や学生諸君および横 浜国立大学の学生諸君, (株) シーアールエスおよび(株) 八重州土木技術センターに多大なご協力を頂きました。 また, 東京工業大学, 建設省土木研究所, 運輸省港湾技術 研究所, 五洋建設技術研究所の方々から計測器を貸して 頂きました.以上の関係者に謝意を表する次第である.

\section{参考文 献}

池野正明・清水隆夫・久保道仁・定森良夫 (1998)：波の多方向 不規則性と浮遊漂砂を考慮した 3 次元海浜変形数值予測モ デルの開発と検証, 海岸工学論文集, 第 45 巻, pp. 531-535.

片山裕之・岡安章夫・永田達也（1999）：連続採水による現地砕 波帯浮遊砂濃度および粒度分布の時系列変化, 海岸工.学論文 集, 第 46 巻, pp. 571-575.

柴山知也・Winyu. Rattanapitikon - 岡安章夫（1994）：砕波帯内 の浮遊漂砂量の算定モデル, 海岸工学論文集, 第 41 巻, pp. 431-435.

田中正博 - 井上亮 - 佐藤憤司 - 磯部雅彦 ・渡辺 晃 - 池野正明 清水隆夫（2000）：2粒径混合砂を用いた大型海浜断面実験 と粒径別漂砂量の算出, 海岸工学論文集, 第 47 巻, pp. 551-555.

張 達平・田中茂信・山本幸次 (1994)：大型 2 次元水路による 海浜砂の分級機構に関する研究, 海岸工学論文集, 第 41 巻, pp. 361-365.

張 達平・山本幸次・佐藤壃司・田中茂信 (1995)：混合砂の分 級過程に関する実験的研究, 海岸工学論文集, 第 42 巻, pp. 481-485.

張 達平・佐藤壃司・戸崎正明・田中茂信 (1996)：混合砂海浜 の断面変形と粒径別漂砂量に関する実験的研究, 海岸工学論 文集, 第 43 巻, pp. 461-465.

張 達平・佐藤䱋司・山本幸次・田中茂信（1997）：不規則波に よる浮遊砂輸送とバー地形の発達に関する大型実験, 海岸工 学論文集, 第 44 巻, pp. 481-485.

Ikeno, M. and T. Shimizu (1998): Characteristics of suspended sediment transport in the surf zone of irregular waves and their reproduction by a cross-shore beach deformation model, Proc. 26 th Int. Conf. on the Coastal Eng., pp. 2317-2330.

Nielsen, P. (1988): Three simple models of wave sediment transport, Coastal Eng., Vol. 12, pp. 43-62.

Nielsen, P. (1992): Combined convection-diffusion modeling of sediment entrainment, Proc. 23 rd Int. Conf. on the Coastal Eng., pp. 3202-3215. 